\title{
ZOFIA KATARZYNA BRANICKA ODESCALCHI ZWANA PIERWSZYM „POLSKIM PAPIEŻEM”"
}

Księżna Zofia Katarzyna z Branickich Odescalchi niemal pół wieku spędziła w Rzymie. Zasłynęła jako ,,arystokratka wpływowa w sferach watykańskich” (Wszołek, „Zofia Katarzyna Odeschalchi” 535). Uzyskała tak znaczącą pozycję w zakresie spraw polskich, a zwłaszcza kościelnych, że nazywana była przez ówczesnych ,polską ambasador” przy Watykanie lub wręcz ,papa polacco”, ,papieżem polskim” (Biliński, 303; Bełczowski 13; Barańska 77, 94, 104). W latach od 40. do 70. XIX wieku pałac księżnej stał się ,,rodzajem polskiej placówki przy dworze rzymskim” (Beiersdorf 508). Odznaczająca się religijnością i przywiązaniem do Kościoła „devotissima principessa Sofia” zyskała do tego stopnia zaufanie papieża Piusa IX, że niejednokrotnie w sprawach polskich miała wpływ na jego decyzje (Lewak 147; Kania 58-59; Barańska 104).

Ta tak znacząca dla historii polskiej XIX wieku, dla relacji polsko-watykańskich i polsko-włoskich nietuzinkowa postać, wprawdzie wzmiankowana w opracowaniach, zwłaszcza dotyczących historii dyplomacji i papieża Piusa IX (zob. bibliografia na końcu artykułu), nie doczekała się dotąd monografii czy też pełniejszego opracowania. Najważniejszą i właściwie jedyną publikacją naukową jej poświęconą jest niedawno wydany obszerny artykuł Anny Barańskiej „,Polska ambasador” przy Watykanie - Zofia z Branickich Odescalchi (1821-1886) (77-132). W ostatnich dosłownie latach ukazało się też kilka artykułów w języku włoskim, w większości raczej o charakterze popularnonaukowym, oraz książek, w których jest wzmiankowana bogata i różnorodna działalność księżnej Zofii (zob. również bibliografia na końcu artykułu).

Dr hab. AgniEsZKa Bender, Instytut Nauk o Sztuce, Katolicki Uniwersytet Lubelski Jana Pawła II; adres do korespondencji: Al. Racławickie 14, 20-950 Lublin; e-mail: agbender@kul.lublin.pl; ORCID 0000-0002-0432-7436 
W pamięci Włochów księżna zapisała się przede wszystkim jako ,principessa generosa”, co należy thumaczyć jako „hojna”, „,szczodrobliwa” lub szerzej - „, szlachetna” czy „wspaniałomyślna”. Podkreśla się przede wszystkim trzy czynniki, które miały wpływ na takie miano. Po pierwsze, dzięki ogromnemu posagowi mogła pomóc odbudować finansowo świetny niegdyś ród Odescalchi (spłacone zostały długi jej męża, wykupiono zastawione księstwo Bracciano i odnowiono zamek, zakupiono nowe dobra, m.in. majątek Bassano). Po drugie, już wkrótce po przybyciu do Italii księżna zasłynęła $\mathrm{z}$ aktywnego wspierania spraw polskich i z roztaczania opieki nad przybywającymi do Rzymu politycznymi emigrantami i artystami. Ostatnim, trzecim powodem dla którego zwano ją ,principessa generosa”, było wielkie zaangażowanie Zofii w sprawy dobroczynności, wyrażające się poprzez pomoc dzieciom, chorym i biednym, fundację szkół i przytułków (Carlino Bandinelli 268; Felluca passim).

Zofia Branicka urodziła się 2 września 1821 roku w Lubomli, w powiecie włodzimierskim, na Wołyniu. Zmarła w pałacu (nazywanym czasem willą) Giustiniani Odescalchi w Bassano di Sutri (obecnie zwanym Bassano Romano) 18 sierpnia w 1886 roku, spoczęła w rodzinnym grobowcu Odescalchich na rzymskim cmentarzu Campo Verano, w części zwanej Rupe Caracciolo. Pochodziła z jednej najzamożniejszych rodzin ówczesnej Europy. Jej rodzicami byli Róża z Potockich (1780-1862) i Władysław Grzegorz Branicki (1782-1843), rosyjski senator i generał armii rosyjskiej. Obaj dziadkowie, Franciszek Ksawery Branicki (1730-1819) oraz Stanisław Szczęsny Potocki (1751-1805), jako Targowiczanie zapisali się niechlubnie w historii Polski. Babka księżnej, słynna i tajemnicza piękność - Aleksandra Engelhardt Branicka (ok. 1754-1838), była domniemaną nieślubną córką Katarzyny Wielkiej (17291796) oraz hrabiego Siergieja Sałtykowa (1726-1765). Aleksandra jako ulubienica carycy i jej dama dworu otrzymywała od niej liczne, rozległe dobra ziemskie i kosztowne podarki. Dodać należy, że sama Katarzyna II, w 1781 roku, wybrała dla niej męża - wspomnianego hetmana Franciszka Ksawerego Branickiego (Wszołek, „Zofia Katarzyna Odeschalchi" 535; Bender passim). Pamiątką po pięknej babce Aleksandrze, jak sugerują to najlepsi włoscy znawcy dawnej biżuterii, był niezwykle okazały i zawrotnie drogi biżuteryjny ensemble (zwany czasem parure) złożony z diademu, naszyjnika i devant de corsage ze spineli, diamentów i pereł, który widoczny jest na kilku portretach Zofii (Giovannini Torelli 1-4; Paolillo passim), oraz przede wszystkim olbrzymi spadek odziedziczony przez Branicką i jej rodzeństwo.

Hrabianka miała dwie siostry, starszą o rok Elżbietę (Elizę) (1820-1876) i młodszą Katarzynę (1825-1907), oraz czterech braci: Franciszka Ksawerego (1816-1879), Aleksandra (1821-1877), Konstantego Grzegorza (1824-1884) i Władysława Michała (1826-1884). Do czternastego roku życia Zofia czas spędzała między pałacami w Lubomli i w Białej Cerkwi, skąd blisko już było do pełnej uroku Aleksandrii, rozległej, złożonej z licznych zabudowań i parku, let- 
niej rezydencji hrabiów Branickich, której nazwa pochodziła od imienia jej założycielki, żony Franciszka Ksawerego (sergekot.com/\%d0\%b0\%d0\%bb\%d0\%b5\%d0\%ba\%d1\%81\%d0\%b0\%d0\%bd\%d0\%b4\%d1\%80\%d0\%b8\%d1\%8f-\%d0\%b1\%d0\%b5\%d0\%bb\%d0\%b0\%d1\%8f-\%d1\%86\%d0\%b5\%d1\%80\%d0\%b a\%d0\%be\%d0\%b2\%d1\%8c/. Dostęp 20.03.2020).

Wówczas, pod kierunkiem francuskich guwernantek, m.in. panny Xaverine (?) Beaupré, odebrała staranne wykształcenie (Załęski 32). Jak wspomina Eliza, dziewczęta miały czas od rana niemal do wieczora wypełniony zajęciami. W latach 1835-1837 wraz z rodzicami i rodzeństwem Zofia przebywała w Petersburgu, gdzie uczyła się języków obcych (francuskiego, angielskiego, niemieckiego i rosyjskiego) oraz pobierała liczne nauki (historii, historii literatury, muzyki, tańca i rysunków). Wraz z Elizą oraz braćmi Władysławem i Aleksandrem (Sudolski 73) była wprowadzana także w życie kulturalne i towarzyskie, zwiedzała Ermitaż, brała udział w różnych balach, spektaklach, koncertach i przyjęciach (Łyszkowska 10-11). Pod koniec 1836 roku Zofia ciężko zachorowała na „żółtaczkę, paraepilepsję i silną anemię”, dlatego wraz z rodzicami zaczęła wyjeżdżać na kuracje do Karlsbadu i Cieplic. Choroba nie ustępowała. W Petersburgu była pod opieką nadwornego lekarza cara Mikołaja I, Niemca - Martina Mandta. W czerwcu 1840 roku udała się „do wód” do Bad Kissingen w Bawarii. Tam poznała księcia Livia III Erba Odescalchiego (1805-1885), oficera w służbie austriackiej, ze znakomitej, ale mocno zubożałej włoskiej rodziny, który oprócz „długich litanii feudalnych tytułów, równie długiego spisu długów i pensji oficera w wojsku austriackim, nic nie posiadał" (Wołyński 2). Na początku września, jak zapisała w jednym z listów Eliza Branicka, matka zaaranżowała zaręczyny. Po kilkumiesięcznym pobycie Zofii w Paryżu, w niecały rok później, 18 lipca 1841 roku, we Frankfurcie odbył się ślub, poprzedzony szczegółowymi ustaleniami dotyczącymi spraw majątkowych (Barańska 82-86). Dzięki posagowi Polki, w 1847 roku odkupiono od księcia Marino Torlonia (1795-1865) zastawione w 1803 roku dobra Bracciano, z malowniczo położonym nad jeziorem potężnym, renesansowym zamkiem, zwanym również Orsini Odescalchi, który do dzisiaj należy do rodziny Odescalchi (Bender 3). Sprawy sądowe jednak ciągnęły się jeszcze długi czas, o czym świadczą zachowane dokumenty ${ }^{1}$. Ogromna budowla „z siedmioma starożytnymi wieżami” była bardzo zaniedbana i wymagała wielu prac remontowych, które opłacane były przez lata z posagu Zofii. W 1952 roku, zgodnie z życzeniem prawnuka księżnej, Livia IV (1913-1981), otwarte zostało zamkowe muzeum i dwadzieścia sal udostępniono dla zwiedzających. Nadmienić

${ }^{1}$ Archivio di Stato di Roma (dalej: ASR), Archivio Odeschalchi (familia) (dalej: AO), sygn. 8A1, n. 4 Copie d'istromenti di vendita di terreni e fabbricati fatta da S.E. il principe D. Marino Torlonia a favore di S. A. la principessa D. Sofia Odescalchi, 1849. 
należy, że tylko w niektórych materiałach dotyczących historii budowli wspominana jest postać zasłużonej dla włoskiej rodziny majętnej księżnej z Polski (Carlino Bandinelli passim; Sodano 33).

Wracając do Zofii, należy stwierdzić, że jak to wynika z różnych relacji, mimo pojawiających się nawrotów choroby, bardzo dobrze szybko zaaklimatyzowała się w nowym miejscu i w nowej sytuacji, a zaaranżowane przez matkę małżeństwo okazało się bardzo udane. Parę łączyły podobne przekonania i głęboka religijność. Oboje wspierali sprawy Kościoła i papieża. Energiczna, pełna inicjatywy Polka znalazła wsparcie i spokój w statecznym mężu, który otaczał ją „,wszelkimi względami i uczuciem" (Barańska 87-90).

Zaraz po ślubie małżonkowie udali się do pięknie położonego średniowiecznego zamku w posiadłości Odescalchich w Ilok nad Dunajem (w Syrmii, we wschodniej Chorwacji). Do Rzymu wracali przez Wiedeń, gdzie księżna została oficjalnie zaprezentowana na dworze cesarskim. Młodzi zamieszkali w centralnym, niezwykle prestiżowym miejscu Wiecznego Miasta, w historycznym pałacu zwanym Chigi-Odescalchi przy Piazza Santi Apostoli. Pełna energii Zofia wkrótce spełniła się jako matka, urodziła Baltazara (1844), Władysława (1846) i Marię della Pace, zwaną Pacettą (1851). W pierwszych latach po ślubie Zofię odwiedzali na dłuższe pobyty członkowie jej licznej najbliższej rodziny, którzy czasem zatrzymywali się w pałacu (wiadomo $\mathrm{z}$ różnych relacji, że przy dłuższych pobytach wynajmowali w pobliżu mieszkania). W 1842 roku przybyli jej rodzice wraz z Elizą, Katarzyną, Aleksandrem i Konstantym. Pobyt, jak wiadomo przede wszystkim z listów Elizy, był bardzo urozmaicony, wypełniony licznymi wyjściami na bale, maskarady, widowiska, spektakle czy na lody do kawiarni przy Piazza di Spagna. Braniccy poznawali miejscowe elity, odwiedzali m.in. salony rodziny Torlonia oraz pałac Farnese. Bywali na wycieczkach archeologicznych z Pietro Ercole Viscontim (1802-1880), archeologiem papieża Piusa IX. Zwiedzali zabytki i zapewne Muzea Watykańskie oraz Muzeum Egipskie. Konstanty w stroju włoskiego myśliwego polował w Rzymskiej Kampanii, a Aleksander brał udział w dysputach filozoficzno-religijno-politycznych z Zygmuntem Krasińskim i jego przyjaciółmi (Gałczyńska 272-274). Od 1845 roku gościł najstarszy brat Zofii, Ksawery, który zażywał kąpieli morskich i dokonywał zakupów wielkich obrazów. W przyszłości stanie się on słynnym kolekcjonerem i właścicielem zamku w Montrésor (Ryszkiewicz 122-123).

Pałac Odescalchich rychło zyskał sławę nie tylko miejsca międzynarodowych spotkań elity arystokratycznej, intelektualnej, dyplomatycznej oraz przedstawicieli najwyższej hierarchii kościelnej i wojskowej, lecz także zaczął pełnić rolę nieoficjalnej ambasady dla polskich emigrantów. Słynne stały się wieczory poniedziałkowe i czwartkowe, w czasie których wkrótce po ślubie Zofii często bywały obie jej siostry, a później krewni z kręgów arystokracji polskiej, włoskiej, rosyjskiej 
i austriackiej. Do stałych gości należeli m.in. książęta: Sermoneta, Colonna, Orsini; kardynałowie: Giuseppe Milesi Pironi Ferretti (1817-1873), Giacomo Antonelli (1806-1876), Luigi Emmanuele Nicolò Lambruschini (1776-1854), Angelo Bianchi (1819-1897), Alessandro Franchi (1819-1878) oraz Lodovico Jacobini (1832-1887), Niemiec Karl August von Reisach (1800-1869), Belg Victor Dechamps (1810-1883) oraz Francuz - dyplomata i prałat Louis-Gaston de Ségur (1820-1881). Z Polaków wymienić należy generała brygady powstania listopadowego, oficera armii Napoleona - Józefa Szymanowskiego (1779-1867); pułkownika w powstaniu listopadowym, generała wojsk tureckich i brytyjskich - Władysława Zamoyskiego (18031868); kardynała prezbitera, nuncjusza Brukseli, najbliższego współpracownika Piusa IX, prymasa Polski - Mieczysława Ledóchowskiego (1822-1902); działacza politycznego, słowianofila - księcia Jerzego Henryka Lubomirskiego (1817-1872). Odwiedzali księżną Odescalchi hrabiowie: działacz emigracyjny - Stanisław Małachowski (1798 lub 1801-1883); działacz społeczny i polityczny - August Cieszkowski (1814-1894); właściciel ziemski, uznawany za „chrześcijańskiego socjalistę” - Leon Rzewuski (1808-1869); właściciel dóbr ziemskich i przemysłowych oraz polityk, mąż Katarzyny, siostry Zofii - Adam Potocki (1812-1872); poeta - wieszcz, mąż Elizy, siostry Zofii - Zygmunt Krasiński (1812-1859). Częstymi gośćmi byli zmartwychwstańcy: ks. Hieronim Kajsiewicz (1812-1873) i ks. Piotr Semenenko (1814-1886). Uczestnikiem spotkań był też późniejszy sekretarz osobisty Piusa IX i kardynał Włodzimierz Czacki (1834-1888), który zamieszkał jako nastolatek w pałacu Odescalchi u ciotecznej siostry matki (Pukianiec 144-145).

Salon słynącej z wielkiej urody i wykształcenia polskiej księżnej w pałacu Odescalchi stał się - z jednej strony - jednym z najważniejszych miejsc spotkań ludzi kultury z różnych stron Europy w drugiej połowie XIX wieku w Rzymie (Carlino Bandinelli 270), z drugiej zaś - a może przede wszystkim - był skupiającym Polonię, pod przewodnictwem Branickiej Odescalchi, wpływowym ośrodkiem, skutecznie oddziałującym w sprawach polskich na poczynania Kurii Rzymskiej (Beiersdorf 508). Jak zaznacza Zbigniew Sudolski, salon stanowił też ważne miejsce wymiany myśli między przedstawicielami władz kościelnych i politycznych, będąc istotnym wsparciem dla polityki papieskiej (Krasiński 75).

Najważniejszą postacią, z którą księżna Zofia - jak podkreślają badacze - miała kontakt niemal na co dzień i z którą łączyły ją szczególne, przyjacielskie wręcz więzi, był ówczesny papież Pius IX (1792-1878), którego ponad trzydziestojednoletni pontyfikat okazał się najdłuższy w historii (Lis, Pius IX a Polska 22). Branicka i jej otoczenie widziało w Ojcu Świętym opokę spraw polskich. W 1846 roku, kiedy powołany został na tron Stolicy Piotrowej, księżna rodem z Polski była już dobrze zaaklimatyzowana w Rzymie. W dniu 22 lutego 1848 roku Zofia, w towarzystwie siostry Elizy, została po raz pierwszy przyjęta przez papieża na prywatnej audiencji, 
w czasie której „,z ogniem” obie panie przedstawiały prześladowania religii i cierpienia narodu polskiego. W odpowiedzi Pio Nono miał stwierdzić, że zna historię Polski i modli się za nią co dzień i zachęca do wspólnych modlitw razem z nim. Kierujący agencją rzymską delegat dyplomatyczny Hotelu Lambert - Ludwik Orpiszewski (1810-1875), w swojej relacji z 1848 roku z podziwem pisał, że księżna „kłóci się o Polskę z całym światem” i dodał „Nieoszacowane są kobiety te wszystkie Branickie" (Kania 58, 237). Podczas tej audiencji Zofia zapewniła Piusa IX o gotowości Polaków jego wsparcia „ochotnikiem i groszem”. Zapewne wtedy też „pobożna polska niewiasta” zwróciła się z prośbą do papieża o zatwierdzenie Bractwa Miłosierdzia Bożego dla Polski. Członkowie Bractwa mieli praktykować miłosierdzie wobec bliźniego. Dzieło to papież zatwierdził 10 lipca 1848 roku (Bełczowski 13). „Devotissima principessa Sofia” (oddana księżna Zofia) pozyskała zaufanie papieża i łatwy dostęp do pokoi Watykanu, po którym - jak później pisano - „snuła się nieustannie” (Lewak 147).

Czasy stawały się coraz bardziej niepewne i wiosną 1848 roku zapobiegliwa Zofia wzięła udział w organizowanych w jednym ze szpitali kursach opatrywania ran. Zapewne w poniedziałek po Wielkanocy siostry Branickie, Zofia i Eliza, zostały powtórnie przyjęte przez papieża. Pius IX miał wówczas wyrazić życzenie, aby powstała kongregacja religijna, której zadaniem byłoby odwrócenie negatywnych skutków, jakie niesie Polsce herezja towianizmu. Państwo Kościelne coraz bardziej słabło, w Rzymie w końcu kwietnia doszło do krwawych rozruchów. Z bronią w ręku bronili go tak bliscy ideowo księżnej, m.in. Zygmunt Krasiński i Cyprian Kamil Norwid (Sudolski 211-213). Gdy papież w listopadzie tegoż roku, po ucieczce z Rzymu, znalazł schronienie na terenie Królestwa Sycylii w Gaecie, księżna przekazywała mu wyrazy solidarności i poparcia (Barańska 94-96; Bełczowski 13). Wkrótce po przekształceniu Państwa Kościelnego w republikę rzymską, co uchwaliło Zgromadzenie Konstytucyjne 9 lutego 1949 roku, księżna Zofia ponownie została przyjęta przez Piusa IX w Gaecie, który przekazał jej „,wiele rzeczy mocnych, pięknych, budujących" (Sudolski 236).

W kwietniu 1850 roku Ojciec Święty powrócił do Rzymu. Spotkania Zofii z papieżem, które stały się coraz częstsze, niewątpliwie były ważne dla obu stron. Pio Nono i księżną Odescalchi łączyło wiele. Oboje pochodzili z utytułowanych rodów arystokratycznych, oboje też od dzieciństwa ciężko chorowali (cierpieli na padaczkę); papież i Zofia - osoby bardzo religijne, ale i aktywne, wykazywali wielką wrażliwość na problemy biednych i dzieci, z zaangażowaniem prowadzili działalność charytatywną. Wreszcie oboje, mimo bardzo wysokiej pozycji społecznej, ciągle żyli w niepokoju związanym z losem ich państw. Oboje też popierali ultramontanizm. Księżna wspierała Piusa IX poprzez liczne działania i zapewne ofiarowała mu pomoc materialną, papież zaś - jak żaden inny wcześniej, mimo tak złożonej 
i niepewnej sytuacji Państwa Kościelnego - wielokrotnie stanowczo występował w sprawach polskich, narażając się na ostre reakcje zwłaszcza ze strony Rosji. Wśród ciemiężonych przez zaborców Polaków uzyskał miano Defensor Poloniae. W korespondencji Pius IX nazywał Zofię „la più pia principessa romana”, co thumaczyć należy „najbardziej pobożna/miłosierna/szlachetna rzymska księżna”. Branicka Odescalchi w listach zwracała się do papieża bardzo bezpośrednio: „Amico” („Przyjacielu”) lub nawet „Zio” („Wujku”) (Krasiński 76).

W tym czasie życie religijne księżnej Zofii dalej się pogłębiało, czemu towarzyszyły dziesięcioletnie prywatne studia z filozofii i teologii, odbyte pod kierunkiem ks. Piotra Semenenki (Sudolski 277-278, 298, 368; Barańska 97). Księżna podjęła też szeroko zakrojoną współpracę z księżmi zmartwychwstańcami, z którymi podzielała poglądy na wiele spraw. Uważali oni, podobnie jak i Zofia, że jedyną drogą pozwalającą na odbudowę Polski jest przede wszystkim duchowe oraz moralne odrodzenie Polaków. Zofia także długo finansowo wspierała zakon (Kania 54-59; Bełczowski 13).

Wielką zasługą księżnej Branickiej Odescalchi była jej wielostronna aktywność i pomoc w założeniu Kolegium Polskiego w Rzymie (Kajsiewicz 62). Idea jego powstania przyświecała księżom Zmartwychwstania Pańskiego już w latach 40. XIX wieku. Podejmowane pewne kroki w tym celu okazały się jednak nieskuteczne. Dopiero czas po powstaniu styczniowym oraz silna pozycja w kręgach watykańskich księżnej Zofii i jej kuzyna Włodzimierza Czackiego umożliwiły realizację wcześniejszych zamierzeń, co wymagało jednak wielu starań i uporu, pokonania licznych trudności. W jednym z listów Czacki pisał, że z księżną ,walczyli na zabój" o to dzieło (Nawrocki 39-40). Po drodze stawiał opór m.in. kardynał Giacomo Antonelli (1806-1876), rusofil, przeciwny sprawie polskiej. „Szturm [do niego] przypuściła” Branicka Odescalchi. W jednej z rozmów kardynał stwierdził, że Polaków można umieszczać w kolegiach już istniejących. Księżna na to odparła, że Polacy nie ścierpią, by w Rzymie byli gorzej traktowani od innych narodów. Wobec takiego dictum kardynał dłużej się nie upierał i wyraził zgodę na organizację kolegium. Niezbędnym dla jego uruchomienia było zdobycie środków na bursy dla kleryków. Wiosną 1866 roku dysponowano dziewięcioma bursami, z których trzy pochodziły od księżnej Odescalchi. (Jedna z nich trafiła do późniejszego biskupa Józefa Pelczara, który został beatyfikowany i kanonizowany przez papieża Jana Pawła II.) Ojciec Święty miał w tym czasie skonstatować: „Questi poveri Polacchi non hanno oggi loro Sovrano. Ebbene, io sarò in Roma loro Sovrano. Questo Collegio sarà il mio" [Ci biedni Polacy nie mają teraz swojego rządu. Dobrze więc, ja będę ich władcą w Rzymie. To kolegium będzie moim] (100 lecie 23; Lis, „Sprawy polskie" 109), po czym przekazał z własnej szkatuły na fundację kolegium 100000 franków (Lis, „Sprawy polskie” 114). W marcu, w budynku nieopodal 
Forum Romanum, przy via Salaria Vecchia, pod numerami 46-48-50, Papieskie Kolegium Polskie, kierowane przez rektora ks. Piotra Semenenkę, rozpoczęło działalność. Warto nadmienić, że do ostatnich chwil Rosjanie podejmowali wysiłki dyplomatyczne, aby kolegium nie było kierowane przez zmartwychwstańców (Nawrocki 37). W kolejnych latach księżna Zofia nadal aktywnie wspierała tę młodą instytucję; w 1869 roku sfinansowała siedem burs dla studentów (100 lecie 21-25; Stępień 255-257).

Do innych ważnych zasług księżnej Zofii należało wsparcie dla kanonizacji Jozafata Kuncewicza (ok. 1580-1623), unickiego arcybiskupa Połocka. Mimo sprzeciwu rosyjskiego ambasadora odbyła się ona w maju 1865 roku (Barańska 113).

Za sukces działań Branickiej Odescalchi wraz ze zmartwychwstańcami uznaje się wybór Mieczysława hr. Halki Ledóchowskiego (1822-1902) na arcybiskupa Gniezna i Poznania w 1866 roku. Nominacja ta nastąpiła po długich negocjacjach i tarciach dyplomatycznych. Kolejny raz księżna Zofia wykazała się ogromną determinacją, tym razem walcząc o niedopuszczenie niemieckiego kandydata na to stanowisko (Zieliński 140; Barańska 113-115).

Wydarzeniem o znaczeniu historycznym było powierzenie w 1867 roku kuzynowi Zofii, Włodzimierzowi Czackiemu, nieistniejącego wcześniej w dziejach papiestwa urzędu osobistego sekretarza Piusa IX (Nawrocki 41; Kardaś 104-105). Czacki, przez najbliższe otoczenie zwany Mirem, przybył do Rzymu w 1851 roku w wieku szesnastu lat dla podratowania zdrowia. Wybitnie zdolny, ale ciężko chory, w tym na kruchość kości, trafił pod troskliwą opiekę ciotki, zamieszkał w pałacu i kontynuował, na początku codziennie, pod jej okiem naukę (Nawrocki 30). Od najmłodszych lat słynął z łagodnego charakteru, głębokiej religijności, ale i bystrości umysłu oraz wykwintnego, lecz i ciętego dowcipu, ,pełnego soli attyckiej” - jak pisał Paweł Popiel (154). Młody Czacki uczestniczył w słynnych spotkaniach organizowanych przez Branicką Odescalchi, które pozwoliły mu szybko wejść w świat rzymskiej i watykańskiej elity. Wprowadzony przez ciotkę na Watykan, swoją osobowością, głęboką wiarą i inteligencją zwrócił uwagę Piusa IX. Papież podczas późniejszych licznych spotkań okazywał Czackiemu wiele serdeczności, przygotowując go sam do studiów z teologii, zwracał się do niego początkowo „mio caro contino” („mój drogi młody hrabio”). Włodzimierz, który nie mógł klękać, otrzymał święcenia kapłańskie w prywatnej kaplicy pałacowej Odescalchich w 1868 roku. Tam też odprawiał msze święte, a w wolnych chwilach spowiadał młodzież szkolną. Papież mianował poliglotę Czackiego najpierw na cameriere secreto, potem prelato domestico, a następnie na prywatnego sekretarza (Nawrocki 41). Pius IX darzył młodego księdza pełnym zaufaniem. Czacki decydował, kto może być przyjęty na audiencji papieskiej. Po śmierci Piusa IX został nuncjuszem we Francji, a później - w 1882 roku - kardynałem. Włodzimierz Czacki zmarł nagle 
w roku 1888, w wieku pięćdziesięciu czterech lat, i pochowany został „czasowo” na cmentarzu Campo Verano, w kaplicy rodziny Odescalchich. Dopiero dzięki m.in. staraniom zmartwychwstańców i za sprawą Jana Pawła II, w 1982 roku przeniesiono trumnę do krypty w jego tytularnej bazylice św. Pudencjany w Rzymie. Należy dodać, że w świątyni znajduje się tumbowy nagrobek Włodzimierza Czackiego, wykonany w latach 1888-1891 według projektu Piusa Welońskiego (1849-1931), należący do jego czołowych dzieł (Chrzanowski i Kornecki 188-190; Kardaś 107; Rola-Bruni „Narodowa Pielgrzymka Polaków”; www.catholic-hierarchy.org/bishop/ bcza.html. Dostęp 20.03.2020).

Wspomnieć jeszcze należy, że wcześniej księżna Zofia razem ze zmartwychwstańcami bardzo zaangażowała się w pomoc przybyłej do Rzymu jesienią 1845 roku Makrynie Mieczysławskiej (1784?-1869), właściwie Irenie Wińczowej, podającej się za przełożoną klasztoru bazylianek w Mińsku. (Prawda o przeszłości mistyfikatorki wyszła na jaw dopiero kilkadziesiąt lat później, dzięki publikacji Jana Urbana, Makryna Mieczysławska w świetle prawdy, wydanej w 1923 roku nakładem Przegladu Powszechnego.) Relacje „matki Makryny” na temat prześladowań jej i innych zakonnic ze strony caratu wywarły na paryskiej, później rzymskiej elicie, papieżu i księżnej ogromne wrażenie, stawiając Rosję w negatywnym świetle. Przejęta losem Makryny, Zofia zorganizowała razem ze zmartwychwstańcami i miejscowymi Polakami zbiórkę pieniędzy dla bazylianek na zakup oraz remont opuszczonego „klasztorku” i małego kościoła (Casa di San Giuliano), który mieścił się przy dzisiejszym Piazza Vittorio Emanuele, w pobliżu kościoła św. Euzebiusza (Sudolski 473; Barańska 97-98). Księżnej nie były obojętne również losy doczesnych szczątków Makryny. Bazylianka została pochowana na terenie swojego klasztoru, który jednak uległ wyburzeniu w roku 1873. Wówczas trumnę Makryny przeniesiono na Campo Verano, do grobu panny Baupré, guwernantki, a potem damy do towarzystwa Branickiej Odescalchi (Wszołek, „Irena, Julia” 741). Po zlikwidowaniu tego grobu z kolei niewykluczone, że szczątki mniszki mogły zostać umieszczone w kaplicy rodowej Odescalchi, na wspomnianym rzymskim cmentarzu (veranomonumentalcemetery.wordpress.com/people-at-verano/. Dostęp 20.03.2020).

Jeszcze jedną z niepodważalnych zasług księżnej Zofii była pomoc polskim artystom. Wiadomo, że wspierała ona Cypriana Norwida. Pomagała wielu malarzom, fundując im stypendia. We własnym pałacu zorganizowała pracownie Leopoldowi Nowotnemu (1818-1870) i Romanowi Postempskiemu (1808-1878), gdy byli w trudnym położeniu finansowym. Nowotny w swoich pracach podejmował przede wszystkim tak bliskie Zofii tematy religijne, Postempski malował zwłaszcza sceny historyczne i portrety. Nowotny został kustoszem galerii obrazów księżnej (RolaBruni, „Nowotny”). Wiadomo, że z zaangażowaniem zajmował się konserwacją 
zbiorów i ich powiększaniem. W środowisku uchodził za „malarza X. Odescalchi” (Nitka, Twórczość malarzy polskich. Katalog 64-65, 73-74). Obu wspomina syn Zofii, Baltazar. Szczególnie ciepło pisze o Nowotnym, podkreślając, że jego zainteresowanie sztuką narodziło się dzięki wizytom w pracowni tego artysty (Odescalchi 4; Nitka, Twórczość malarzy polskich 100). Najpierw ze zmartwychwstańcami, a później z księżną Odescalchi nawiązał kontakt przybyły do Rzymu w 1852 roku utalentowany malarz Jan Franciszek Drewaczyński (1826-1899). W czasie spotkania w jej salonie w 1859 roku poznał malarza - dominikanina Jana Baptystę Hiacynta Bessona (1816-1861), współzałożyciela Bractwa Świętego Jana Ewangelisty w Rzymie (Horaist 498-499). Pod jego wpływem wstąpił do dominikańskiego zakonu, przybierając imię Angelik. Dominikanie mieli zawdzięczać Drewaczyńskiemu protekcję u księżnej, która ofiarowała im dom Panateri, położony w pobliżu Kwirynału (Nitka, Twórczość malarzy polskich. Katalog 133). Zapewne chodzi o nieruchomość przy Via della Panetteria².

Na zakończenie trzeba dodać, że Zofia co pewien czas miewała nawroty ciężkiej choroby, której wówczas nie potrafiono zdiagnozować. Świadczą o tym listy m.in. jej siostry Elizy, w których wspomina o tych poważnych problemach niezbyt dbającej o swoje zdrowie Zofii (Sudolski 306, 307, 372-373, 505-507). Mąż księżnej, Livio, w lutym 1865 roku także zapisał, że życie jej „toczy się wśród konwulsji, senności, letargu, paplaniny, majaczeń i tysiąca innych niepojętych objawów zrozumiałych tylko dla lekarza" (Sudolski 506). Należy zatem podkreślić, że mimo tych nawracających poważnych dolegliwości, Zofia wykazywała ogromną determinację i potrafiła się mocno, a co najważniejsze - skutecznie angażować w „sprawy polskie” i nie tylko polskie. Pamięć o jej dobroczynności, skierowanej przede wszystkim do mieszkańców Bracciano - dla miejscowego szpitala, przytułku oraz kościoła, pozostała do dzisiaj (Carlino Bandinelli passim; Felluca passim). W „Archivio Odescalchi (familia)” w wielu miejscach znajdują się także informacje o wydatkach Zofii w celu wsparcia różnych rzymskich instytucji, m.in. szpitala dla księży oraz kościołów³.

Księżna Zofia uchodziła nie tylko za urodziwą, ale wręcz piękną dziewczynę, a później kobietę. Taką opinię wyrażało wielu jej współczesnych. Na przykład Gabriela z Güntherów Puzynina we wspomnieniach pisze, iż mówiono na wileńsz-

\footnotetext{
${ }^{2}$ ASO, AO, sygn. 10G16, n. 10 Scandaglio per lavori di manutenzione della casa di Via della Panetteria in Roma, di proprietà di Sofia Odescalchi Branicka, 1885.

${ }^{3}$ ASO, AO, sygn. 8B2, n. 1 Conti relativi alla Opera Pia delle Suore Basiliane Polacche, costituita sotto forma di Società Anonima ad iniziativa e a carico di Sofia Branicka Odescalchi in Roma, per il monastero allestito dinanzi la chiesa di S. Esebio nel rione Esquilino e per l'annessa chiesa, 1848-1856; sygn. 8B2, n. 2 Conti relativi a lavori d'ordine di Sofia Branicka Odescalchi nello stabile di Via Paolina in Roma, adibito ad Ospedale dei Preti; e a spese per il suo funzionamento affidato ai Fate-bene Fratelli, 1853-1854.
} 
czyźnie jesienią 1840 roku o tym, że Mieczysław Przeździecki (syn jej wuja Konstantego) „był raniony w serce, że mu piękna Zofia Branicka, późniejsza księżna Odescalchi, odmówiła wzajemności” (Puzynina 291). Niemal dwadzieścia lat później, w listopadzie 1858 roku, z kolei Eliza w jednym z listów o siostrze napisała: „Zofia piękna i dobra i ekscentryczna jak zwykle” (Sudolski 432).

Wielką urodę księżnej Branickiej Odescalchi potwierdzają portrety, które ukazują kobietę o pociągłej, owalnej twarzy, o bardzo regularnych rysach i włosach koloru kasztanowego, z rudawymi refleksami. Najwcześniejszy znany jej wizerunek pochodzi z ok. 1830-1831 roku. Jest to akwarela Podwójny portret Elizy Krasińskiej (z domu Branickiej) i Zofii Odescalchi (z domu Branickiej), namalowana przez Pietro de Rossiego (1761-1831), znajdująca się w Muzeum Narodowym w Warszawie. W zbiorach tegoż muzeum przechowywana jest również później wykonana przez Alexandra Clarota (1796-1842), także akwarela, z 1837 roku, przedstawiająca poważną, ale i pełną wdzięku nastolatkę (Barańska 82). Ary Scheffer (1795-1858), malarz blisko zaprzyjaźniony z Zygmuntem Krasińskim, z którym też korespondowała księżna, namalował niepublikowany Podwójny portret, olej na płótnie, ukazujący dwie młode kobiety, Elizę i Zofię, który został sprzedany przez paryski antykwariat La Crédence (www.lacredence.com/en/painting/painting-signed-ary-scheffer-antique-dealer-la-credence-paris/. Dostęp 20.03.2020). On wykonał też olejny portret w owalu Zofii z Branickich, powstały później, sygnowany, ale również niedatowany, reprodukowany przynajmniej dwukrotnie, niestety bez podania miejsca przechowywania (Wellisz 99, 132, il. 5; Sudolski il. 65). Z około 1850 roku pochodzi kolejny znakomity portret księżnej, namalowany przez Franza Xavera Winterhaltera (1805-1875), należący do zbiorów Muzeum Narodowego w Warszawie. Dalsza zagadkowa grupa przynajmniej czterech nieukończonych i niesygnowanych, niemal identycznych portretów, wykonanych olejem na płótnie, przechowywana jest w różnych miejscach: w Rzymie - w Museo di Roma w Palazzo Braschi i pałacu rodziny Odescalchi, oraz w Bracciano - w Museo Civico i Museo diocesano del Duomo di S. Stefano. Wszystkie one ukazują Zofię w czerwonej sukni, ze wspaniałą biżuterią, o której już wyżej wspomniano (Felluca 5-7; Bender 7-8). Jedno z płócien, przechowywane przez potomków książęcego rodu, nigdy nie było wcześniej publikowane. Autorka artykułu, dzięki uprzejmości rodziny, prezentowała jego zdjęcie podczas konferencji pod tytułem „Tra Italia e Polonia: arti decorative e design”, która odbyła się w Stacji Naukowej Polskiej Akademii Nauk w Rzymie w czerwcu 2018 roku. Od przedstawicieli rodu Odescalchi uzyskała też wówczas wiadomość o tym, że w zbiorach rodzinnych przechowywane są jeszcze inne, dotąd nieznane obrazy przedstawiające Zofię, których zdjęć do tej pory nie udało się jednak zdobyć. Ostatni z grupy odnalezionych dotąd wizerunków księżnej eksponowany jest w Museo di Roma, w gipsotece Pietro Teneraniego (1789-1869). Jest to gipsowe 
popiersie, z około 1850 roku, które służyło do wykonania marmurowej rzeźby. Na zakończenie należy dodać, że zachowało się też kilka fotografii Zofii. Jedna z nich, ukazująca rodzinę Branickich, została zamieszczona w książce Zbigniewa Sudolskiego (Sudolski il. 31).

W podsumowaniu należy stwierdzić, że zarysowana działalność dyplomatyczna, społeczna, polityczna i mecenasowska księżnej była znacznie bogatsza; powinna stać się tematem dalszych badań naukowych. Branicka Odescalchi we wszystkich swoich inicjatywach miała na względzie sprawy polskie i Kościoła. To, że nazywano ją „polskim papieżem”, było dowodem najwyższego dla niej uznania. Nikt wówczas nie mógł marzyć, że sto lat później Polak zasiądzie na Stolicy Piotrowej.

\section{BIBLIOGRAFIA}

BARAŃSKA, Anna. „«Polska ambasador» przy Watykanie - Zofia z Branickich Odescalchi (18211886)". Od Paryża do Irkucka ... i dalej. Niecodzienne przypadki Polaków okresu niewoli narodowej, red. Anna Barańska i Eugeniusz Niebelski, Towarzystwo Naukowe KUL, 2017, ss. $77-132$.

BEIERSDORF, Otton. „Polska działalność dyplomatyczna w okresie Powstania Styczniowego”. Powstanie Styczniowe 1863-1864. Wrzenie. Bój. Europa. Wizje, red. Sławomir Kalembka, PWN, 1990, ss. 506-540.

Belczowski, Piotr. „Pallotti i Polki”. Pallotti a Polacy. XVIII Sympozjum Instytutu Pallottiego, 26-27.11. 2016, www.instytutpallottiego.pl/wp-content/uploads/2017/11/Pallotti-i-Polki.pdf. Dostęp 20.03.2020.

Bender, Agnieszka. „Sofia Caterina Branicka Odescalchi: ritratto storico”. Tra Italia e Polonia: arti decorative e design [2018, w druku].

BILIŃSKI, Wojciech. „Odescalchi Zofia”. Encyklopedia katolicka, red. Edward Gigilewicz i in., t. 14, Towarzystwo Naukowe KUL, 2010, kol. 302-303.

CARLino, Bandinelli Angela. Bracciano. Negli occhi della memoria. Edizioni Mediterranee, 2004.

Chrzanowski, Tadeusz, i Marian Kornecki. Polskie pomniki w świątyniach Rzymu. Instytut Sztuki PAN, Fundacja Rzymska im. J.S. Umiastowskiej, 1994.

Felluca, Elena. „Sofia Rosa Katharina Branicka Odescalchi”. Lago Sabatino. Archeologia, storia, storia dell'arte, 2019, ss. 1-7, www.lagosabatino.com/2017/sophia-rosa-katharina-branicka-odescalchi/. Dostęp 20.03.2020.

GaŁCZYŃSKA, Cecylia Zofia. „Aleksander Branicki (1821-1877) pierwszy polski archeolog-amator nad Nilem". Materiaty Archeologiczne, t. 40, 2015, ss. 271-298.

Giovannini ToRelli, Guido. «Ancora sugli spinelli. Un Importante Gioiello con Spinelli di Probabile Provenienza Imperiale Russa.» Cultura del Gioiello, 2013, ss. 1-8, culturadelgioiello.wordpress. com/2013/01/09/ancora-sugli-spinelli/. Dostęp 20.03.2020.

Horaist, Bruno. « Hyacinthe Besson et la décoration de la salle capitulaire de Saint-Sixte le Vieux à Rome. » Mélanges de l'école française de Rome. Moyen-Age, Temps modernes, vol. 99, $\mathrm{N}^{\circ} 1$, 1987, ss. 491-513.

KaJSIEwICZ, Hieronim. „Pamiętnik o początkach Zgromadzenia Zmartwychwstania Pańskiego” 2009, biblioteka.xcr.pl/wp-content/uploads/2018/12/KAJSIEWICZ-Pamietnik-o-Poczatkach-CR.pdf. Dostęp 20.03.2020.

Kania, Jan. Pius IX a walka Polaków z Rosją. Powstanie Styczniowe (1863-1864). Studia z dziejów 
stosunków polsko-watykańskich. Wydawnictwo Spes, 2000.

KARDAŚ, Artur. „Kardynał Włodzimierz Czacki”. Zeszyty Historyczno-Teologiczne. Rocznik Zmartwychwstańców, t. 22, 2016, ss. 103-108.

KrASIŃSKI, Zygmunt. Riflessi inediti del Risorgimento nelle lettere dall'Italia, oprac., wstęp i thum. Iwona Dorota Moncalieri. Cenro interuniversitario di ricerche sul „Viaggio in Italia”, 2018.

LEWAK, Adam. „Polska akcja dyplomatyczna w Watykanie”. Polska działalność dyplomatyczna 18631864. Zbiór dokumentów, red. Adam Lewak, t. 2, PWN, 1963, ss. 141-177.

Lis, Krzysztof. Pius IX a Polska w dobie powstania styczniowego. Katolicki Uniwersytet Lubelski, 1996.

Lis, Krzysztof. „Sprawy polskie w pontyfikacie Piusa IX (1846-1878)”. Saeculum Christianum, t. 8, nr 1, 2001, ss. 101-125.

Łyszkowska, Aldona. „Dziewczęta ze stepów”. Muzealne Rozmaitości, nr 1(5), 2017, ss. 10-11, docplayer.pl/60542687-Muzealne-ealn-ne-52-0-72c.html. Dostęp 20.03.2020.

Nawrocki, Michał. „Kardynał Włodzimierz Czacki”. Rocznik Kolegium Polskiego w Rzymie, z. 6, 1904, ss. 21-63.

NiTKA, Maria. Twórczość malarzy polskich w papieskim Rzymie w XIX wieku. Wydawnictwo Tako, 2014.

NitKA, Maria. Twórczość malarzy polskich w papieskim Rzymie w XIX wieku, cz. 2 Katalog. Wydawnictwo Tako, 2014.

OdesCalchi, Baltazar. „Polacy w Rzymie. Wspomnienia z lat dziecinnych”. Kraj, nr 49, 1893, ss. 1, 4-5.

Paolillo, Ciro. «Sofia Caterina Branicka Odescalchi: la Principessa generosa.» Tra Italia e Polonia: arti decorative e design [2018, w druku].

Popiel, Paweł. Pamiętniki Pawła Popiela (1807-1892). Krakowska Spółka Wydawnicza, 1927.

PukiAniec, Mikołaj. «La Sede Apostolica nei confronti dei Polacchi prima Della Grande guerra.» Atti dell'Accademia Polacca, vol. 4, 2014-2015, pp. 144-155.

PuZynina, Gabriela. W Wilnie $i$ w dworach litewskich: pamiętnik z lat 1815-1843. druk Józefa Zawadzkiego, 1928.

Rola-Bruni, Agata. „Nowotny - biografia nowoodkryta”. Nasz Świat, 2017, naszswiat.it/polacy-we-wloszech/nowotny-biografia-nowoodkryta/. Dostęp 20.03.2020.

Rola-Bruni, Agata. „Narodowa Pielgrzymka Polaków do Rzymu w roku 1888. Wspomnienie w 130. Rocznicę wydarzeń”. Nasz Świat, 2018, naszswiat.it/polacy-we-wloszech/nowotny-biografia-nowoodkryta/. Dostęp 20.03.2020.

RYsZKiewicz, Andrzej. Kolekcjonerzy i mitośnicy. PWN, 1981.

Sodano, Cecilia. «Un progetto di ricerca sul castello Orsini Odescalchi di Bracciano: prime ipotesi interpretative.» Parte II. Recupero e conservazione magazine, No 144, 2017, ss. 24-35.

STĘPIEŃ, Marek. „Erygowanie i początki funkcjonowania Papieskiego Kolegium Polskiego w Rzymie w XIX w." Prawo Kanoniczne, t. 53, nr 3-4, 2010, ss. 245-259.

Sudolski, Zbigniew. W błękitnym kręgu. Opowieść o Elizie z Branickich Krasińskiej i jej środowisku. Wyższa Szkoła Humanistyczna im. A. Gieysztora w Pułtusku, 2004.

Wellisz, Leopold. Les Amis Romantiques. Ary Scheffer et ses amis polonais. Éditions du Trianon, 1933.

WoŁYŃski, Artur. „Księżna Zofia z Branickich Odescalchi i jej działalność w Rzymie. Wspomnienie pośmiertne". Kraj, nr 43, 1886, ss. 2-3.

WszoŁeK, Jan. „Irena Julia Makryna Mieczysławska”. Polski słownik biograficzny, t. 20, 1975, ss. 739-741.

WszoŁek, Jan. „Zofia Katarzyna Odescalchi (z domu Branicka)”. Polski słownik biograficzny, t. 23, 1978, ss. 535.

ZAŁĘSKI, Krzysztof. „Rysunki ze zbiorów wilanowskich w Muzeum Narodowym w Warszawie”. Studia Wilanowskie, t. 7, 1981, ss. 27-38. 
ZIELIŃSKI, Zygmunt. „Geneza kandydatury Mieczysława Halki Ledóchowskiego na arcybiskupstwo w Gnieźnie i w Poznaniu”. Ecclesia. Studia z Dziejów Wielkopolski, t. 1, 2003, ss. 135-144. 100 lecie Papieskiego Kolegium Polskiego w Rzymie. Drukarnia Watykańska „Poliglotta”, 1966.

\section{Netografia}

Belaya Tserkov' [Белая Церковь], sergekot.com/\%d0\%b1\%d0\%b5\%d0\%bb\%d0\%b0\%d1\%8f-\%d1\% 86\%d0\%b5\%d1\%80\%d0\%ba\%d0\%be\%d0\%b2\%d1\%8c/. Dostęp 20.03.2020.

Double portrait signed Ary Scheffer (1795-1858), www.lacredence.com/en/painting/painting-signed-ary-scheffer-antique-dealer-la-credence-paris/. Dostęp 20.03.2020.

People at Verano, veranomonumentalcemetery.wordpress.com/people-at-verano/. Dostęp 20.03.2020. Włodzimierz Cardinal Czacki, www.catholic-hierarchy.org/bishop/bcza.html. Dostęp 20.03.2020.

\section{ZOFIA KATARZYNA BRANICKA ODESCALCHI ZWANA PIERWSZYM „POLSKIM PAPIEŻEM”}

\section{Streszczenie}

Zofia Branicka (1821-1886) była polską, niezwykle zamożną arystokratką, która w 1841 roku poślubiła włoskiego księcia Livia III Erba Odescalchi. Od tego czasu do śmierci mieszkała w Rzymie. Dzięki olbrzymiemu posagowi księżnej rodzina Odescalchi mogła między innymi odkupić od rodziny Torlonia zamek w Bracciano (niedaleko Rzymu). Zofia otrzymała bardzo staranne wykształcenie, znała biegle kilka języków. Od samego początku swego pobytu w Rzymie zaczęła organizować słynne wieczorne spotkania w salonie, w Pałacu Odescalchi. W ten sposób księżna Zofia skupiała elitę arystokracji, dyplomacji i kleru z różnych krajów europejskich. Wkrótce poznała też papieża Piusa IX, z którym połączyła ją więź wieloletniej przyjaźni. Zofia bezpośrednio informowała papieża o złożonej ówcześnie sytuacji Polski, która była pod rozbiorami. Od początku pobytu we Włoszech zaangażowała się w pomoc charytatywną ubogim. Księżna była też bardzo zaangażowana w finansową i organizacyjną pomoc Polakom we Włoszech (emigrantom, powstańcom, księżom, artystom, takim jak Cyprian Kamil Norwid, Leopold Nowotny, Roman Postempski i inni). Ściśle współpracowała ze Zgromadzeniem Zmartwychwstania Pana Naszego Jezusa Chrystusa w organizowaniu Polskiego Seminarium w Rzymie, które zostało otwarte w 1866 roku. Było to niezwykle doniosłe i ważne wydarzenie dla Polaków, którzy w tym czasie nie mieli swojego państwa. Dzięki głębokiej religijności i patriotycznej działalności, księżna Zofia była wśród swoich rodaków nazywana „polskim papieżem”. Nikt w tamtych czasach nie przypuszczał, że sto lat później Karol Wojtyła zostanie prawdziwym pierwszym polskim papieżem.

Słowa kluczowe: Zofia Katarzyna Branicka Odescalchi; Rzym; Watykan; polski papież; sprawy polskie. 


\section{ZOFIA KATARZYNA BRANICKA ODESCALCHI \\ - THE FIRST "POLISH POPE"}

\section{Sum mary}

Zofia Branicka (1821-1886) was a Polish wealthy noblewoman who married Italian Prince Livio III Erba Odescalchi (1805-1885) in 1841. From then on until her death she lived in Rome. Thanks to her opulent dowry, Odescalchi family could buy back among others, the Bracciano castle (near Rome) from the Torlonia family. Zofia was very well educated and a polyglot. From the very first years of her stay in Rome, she started to organise famous soirees at her salon in Palazzo Odescalchi. In this way Princess Zofia gathered the elite of aristocracy, diplomacy and the clergy, from different European countries. Soon she had a possibility to get to know the pope Pius IX, with whom she would maintain a real and close friendship. Zofia had informed the pope about the complex situation of Poland, partitioned by her neighbours. From the beginning of her stay in Italy she was involved in charity work. The princess was very involved in financial and organisational help to Polish people in Italy (emigrees, insurgents, priests, artists as Cyprian Kamil Norwid, Leopold Nowotny, Roman Postempski etc.). She closely co-operated with The Congregation of the Resurrection of Our Lord Jesus Christ in organising the Polish Seminar in Rome in 1866. That was an event of a great importance for Polish people who at that time had no country of their own. Thanks to her deep religiosity and patriotic activity Princess Zofia was known among her contemporaries as "the Polish pope". Nobody at that time could have imagine that after one hundred years Karol Wojtyła would become the first actual Polish pope.

Keywords: Zofia Katarzyna Branicka Odescalchi; Rome; Vatican, Polish pope; Polish affairs. 


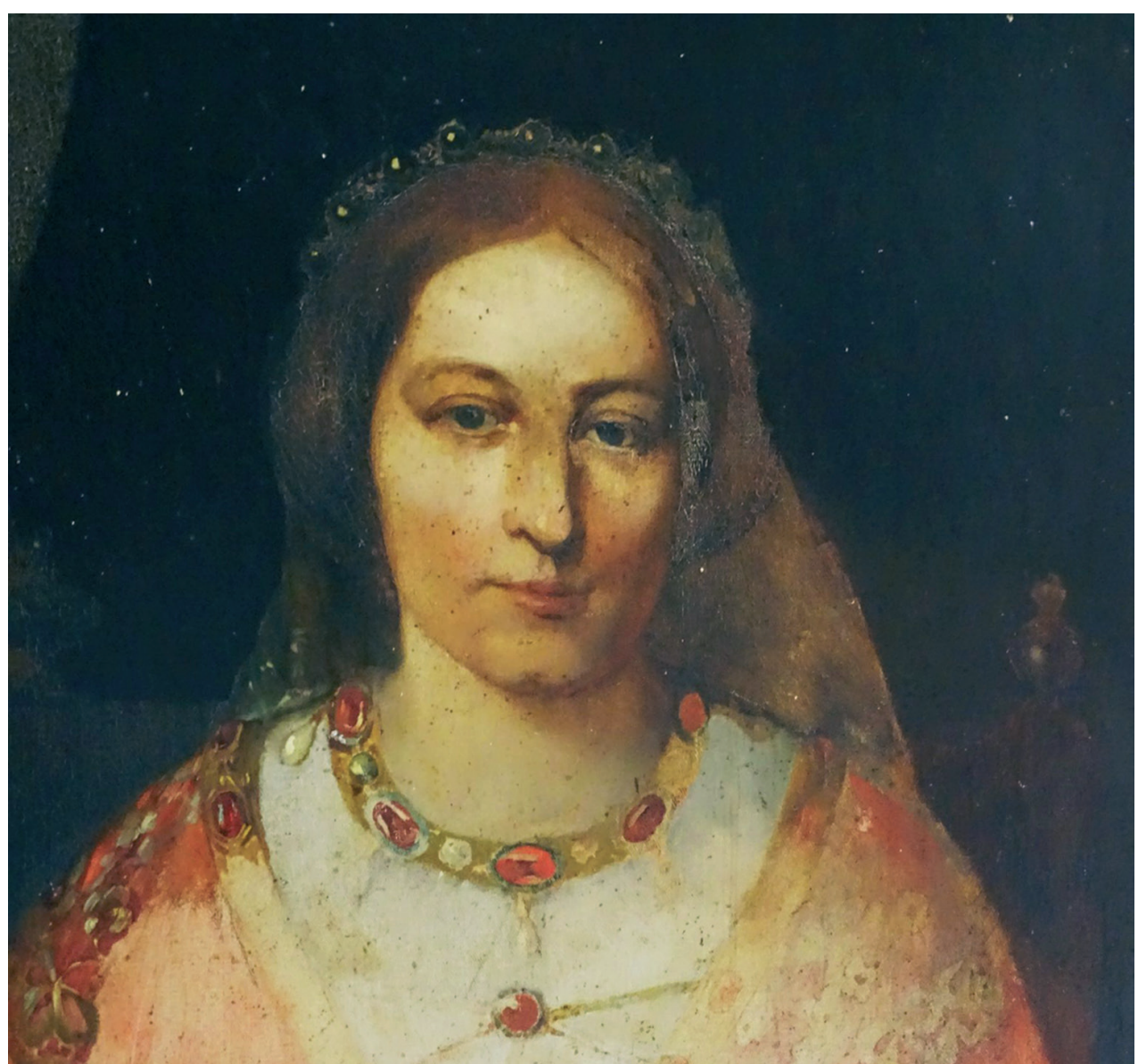

1. Portret Zofii Katarzyny Branickiej Odescalchi (fragment), Museo diocesano del Duomo di S. Stefano, Bracciano, fot. Małgorzata Wrześniak 


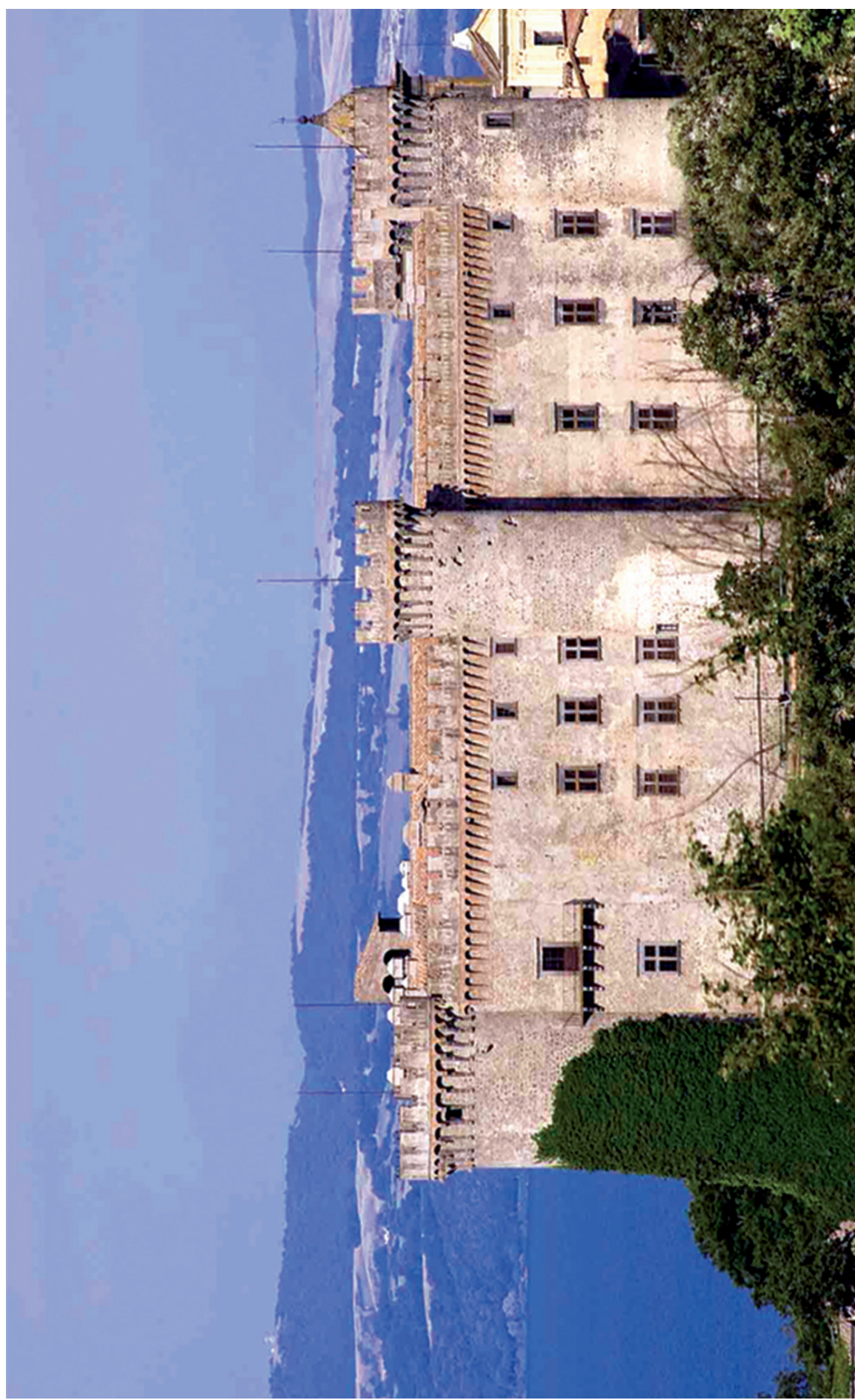




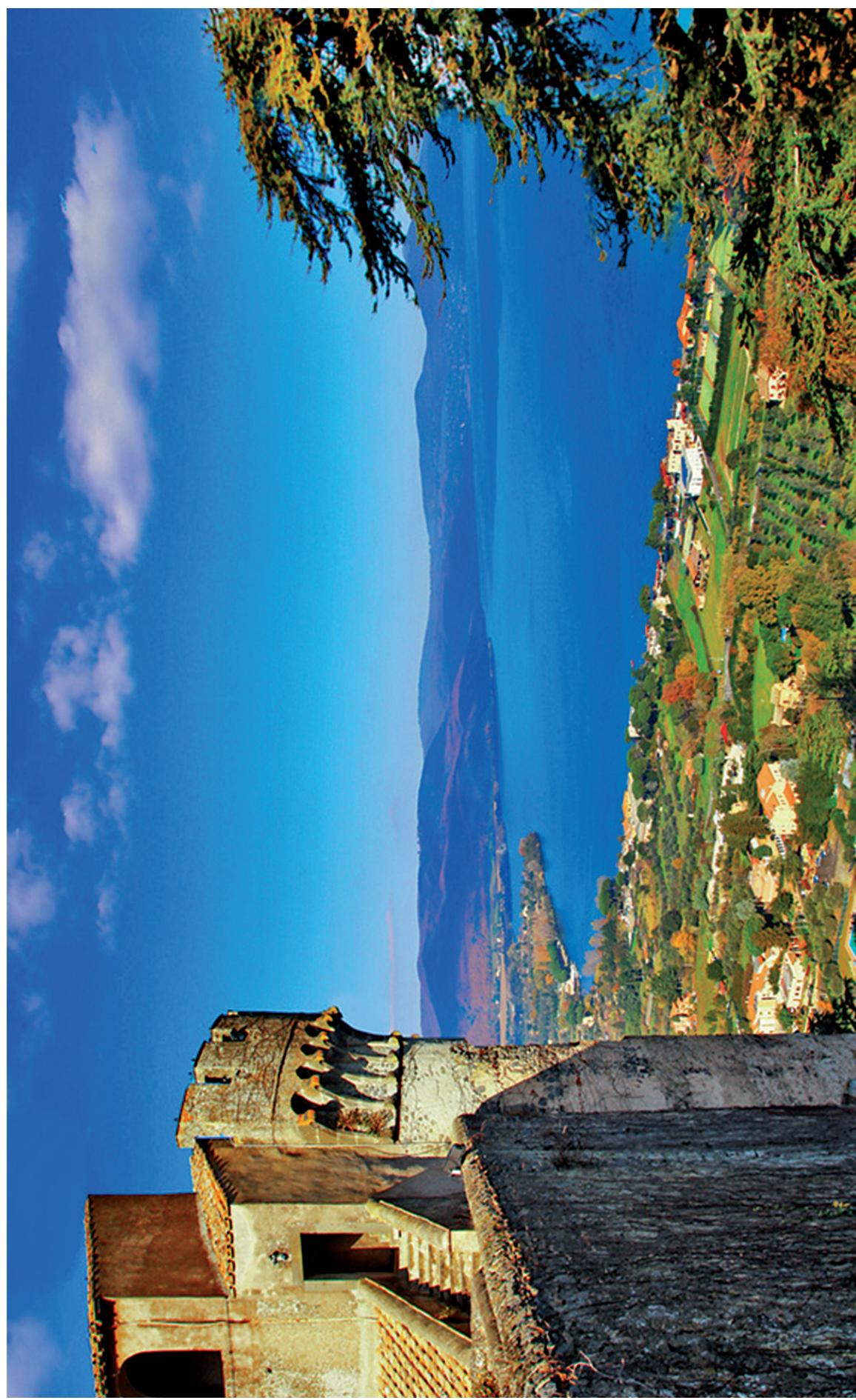

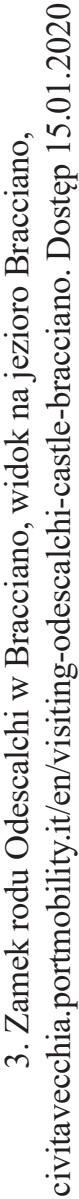




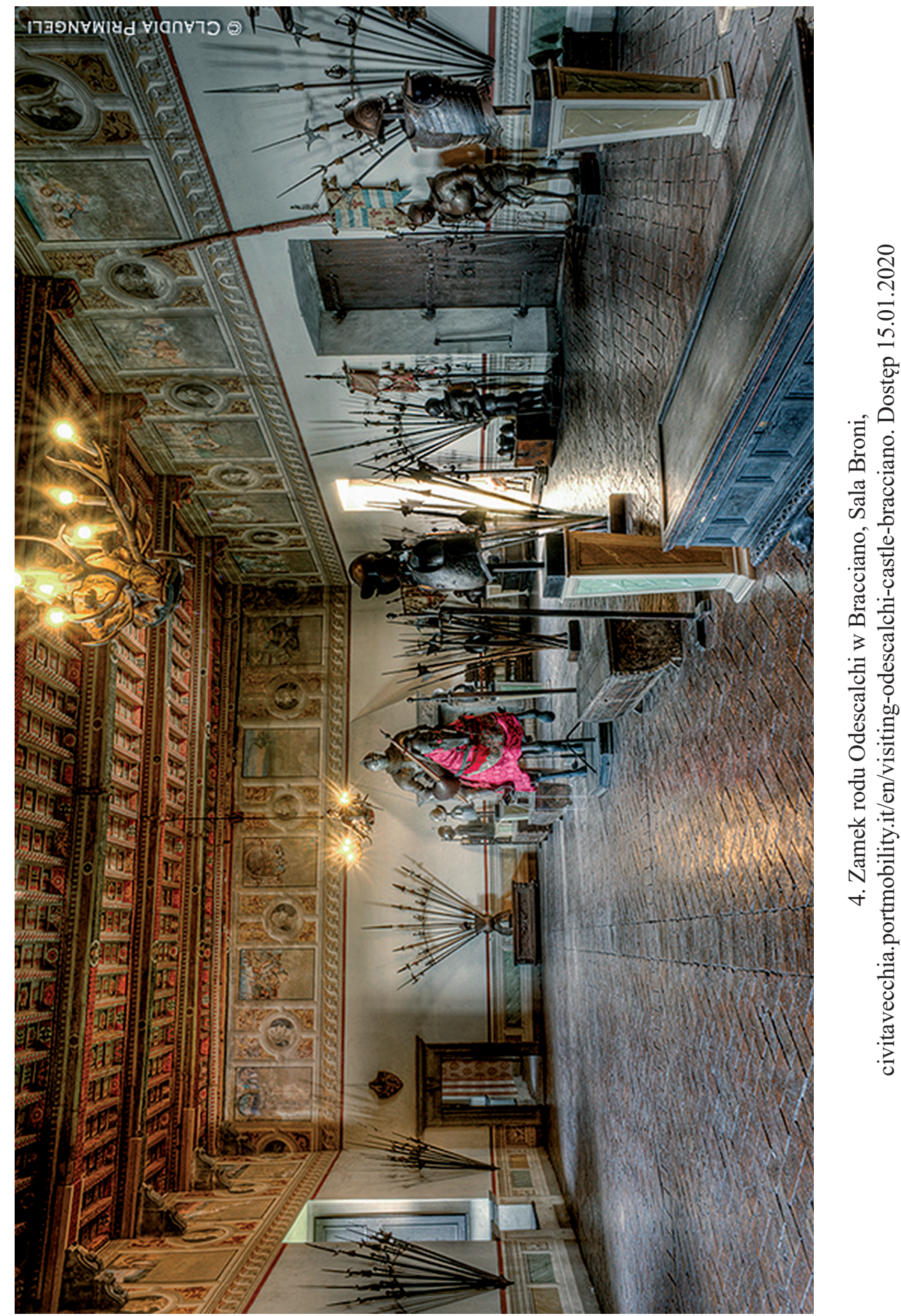




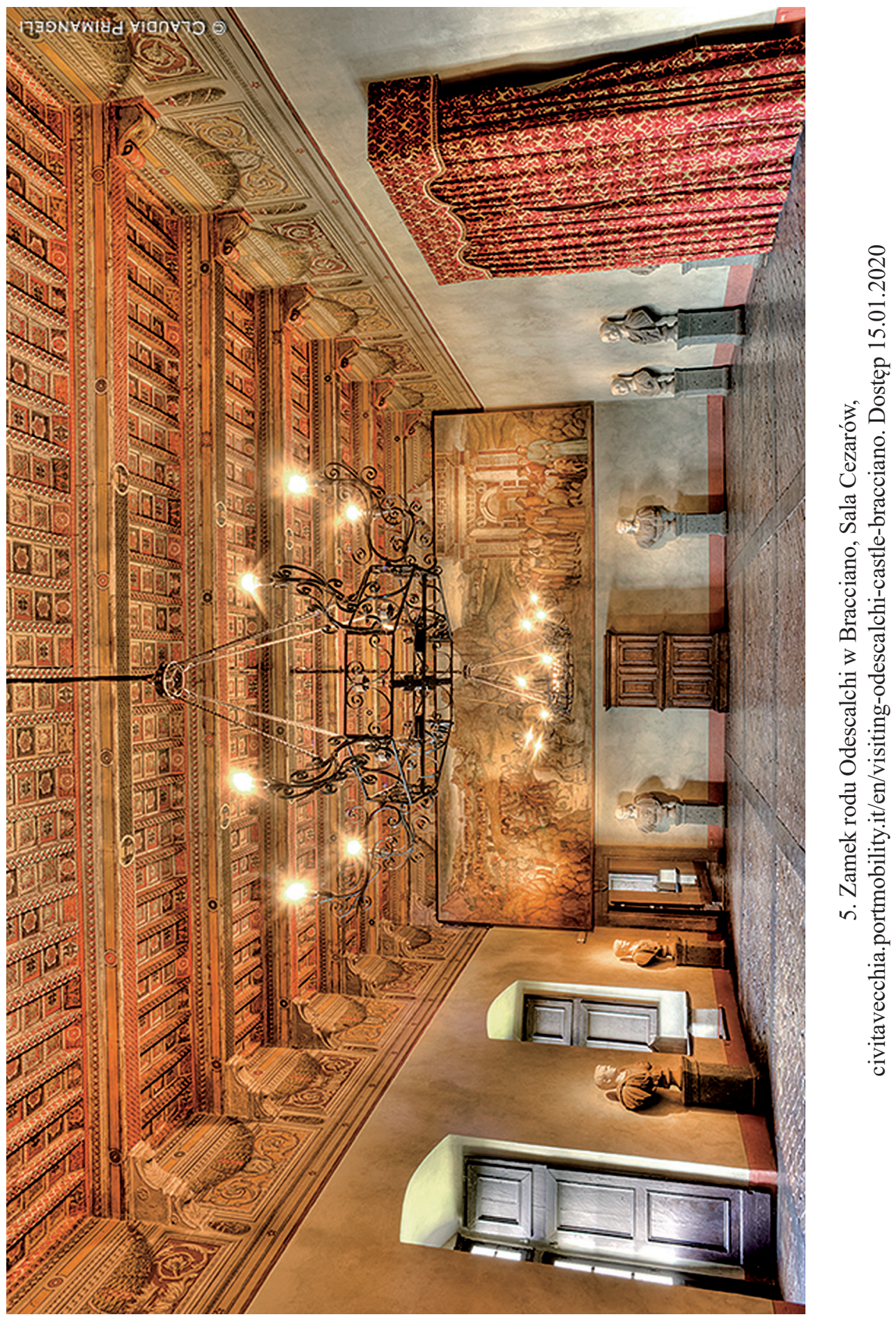




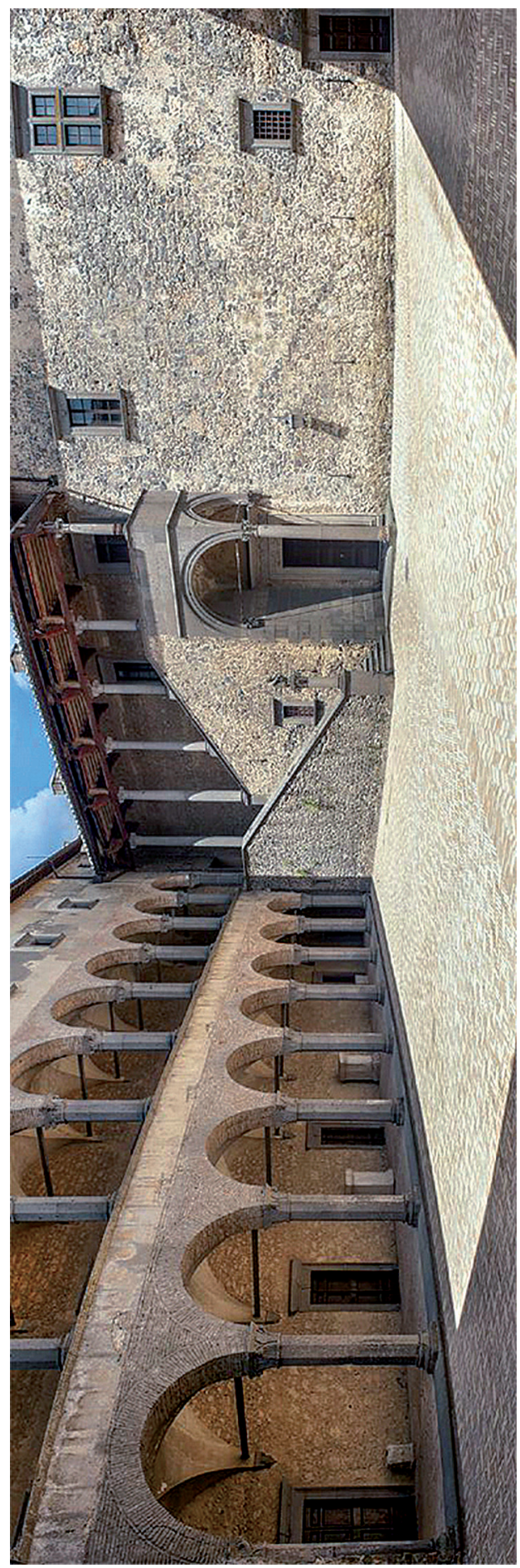

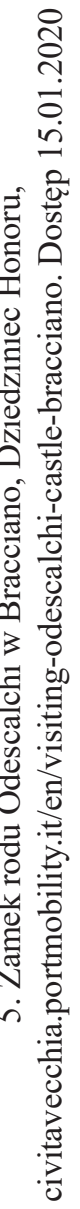

